\title{
On the Toponymy of the Iranian Azerbaijan
}

\author{
Alice Assadorian \\ Islamic Azad University at Tehran North Branch, Tehran, Iran \\ Email: dr.aliceassadorian@gmail.com
}

How to cite this paper: Assadorian, A. (2017). On the Toponymy of the Iranian Azerbaijan. Advances in Anthropology, 7, 146-153.

https://doi.org/10.4236/aa.2017.73010

Received: July 5, 2017

Accepted: August 27, 2017

Published: August 30, 2017

Copyright $\odot 2017$ by author and Scientific Research Publishing Inc. This work is licensed under the Creative Commons Attribution International License (CC BY 4.0).

http://creativecommons.org/licenses/by/4.0/

\begin{abstract}
The article is a tentative classification of the toponymy of the Turkish speaking Iranian regions, now including Eastern and Western Azerbaijans, Ardabil, Zanjan and Ghazvin Provinces. Based on a comprehensive study the writer did, as of 2008, a database of 12,000 Iranian toponyms was collected from the series of volumes of Farhang-e joprāfyāyīi-e İrān, (Iranian Geographical Encyclopedia), published by the Persian Army Survey (1949-1982). In addition, information was collected from local private libraries, and scattered articles from patriotic scholars like Ahmad Kasravi ${ }^{1}$. Finally, to update the data, due to the socio-political developments affecting the toponymy of the country during the recent years, several field studies were also done in the various provinces of Iran including Ardabil, Eastern and Western Azerbaijans, Kurdistan, Gilan, Mazandaran and Khorasan. The collected data were categorized from different aspects regarding the origin of the toponyms, their meanings, and their word formation procedures. This article aims to provide evidence that the original Iranian elements are present in the toponymy of Iran, including all Turkish speaking provinces, and that the linguistic shift from Persian to Turkish in the region, has by no means affected the ethnic Iranian characteristics and identity of its population, against all propaganda to impose Turkish origins and identity to the people of the region. The focus of the study was to locate the common Iranian topoformant suffixes found in the place names throughout the country. The article casts a particular look at the tentative etymology of a place name of the Iranian origin ( $\check{S} \bar{a} m$-aspì $)$, attested in Ardabil district.
\end{abstract}

\section{Keywords}

Toponymy, Topoformants, Azerbaijan, Iranian Place Names

\section{Introduction}

As a melting pot of cultures, Iran has always been the crossroad of ethnic migra-

${ }^{1}$ Kasravī, A. Nāmhā-ye šahrhā va dehhā-ye İrān, I, II. Tehran, entešārāt-e mouqūaàt-e Mahmūd Afšār Yazdī, (1918; 1919). 
tions and the arena of many crucial events. Located in the northwestern borders, the traditional Azerbaijan, now geographically separated into the Turkish speaking provinces of Eastern and Western Azerbaijans, Ardabil, Zanjan and Ghazvin provinces, stood as a strong center of the Iranian culture and the focus of various socio-political developments in the region. Nonetheless, the pan Turkist propaganda emerged around the World War I, aiming to attack on the territorial integrity of Iran, focuses on the Turkish speaking people of the Azerbaijan of Iran, making all kinds of attempts to persuade the people in these areas to secede from the larger political entities to which they belong, and join the Turkish community. The vast propaganda by the social media, offering different services to Turkish speaking youth in Iran is a proof of the fact, and together with the limiting conditions in the present Iran, help convince the people of the region to believe in some fake Turkish origins and belongings. Unfolding the more recent layers of the toponyms can clarify that the linguistic turkification cannot question the ethnic Iranian characteristics and identity of its population.

Toponymical studies are valuable in a vast, multicultural country like Iran with a centuries old history. Toponyms are those linguistic elements that not only reflect the ethnographic picture of a given area, but also reveal the linguistic identity of its primary dwellers and later occupants and invaders. Azerbaijan, and the Azari speaking people in Iran, played a crucial role, during the history, in the formation and all major developments of the country, and separating it from the rest of Iran merely because the language was changed due to historical events, will not erase the ethnic Iranian characteristics and identity of its population.

\section{The Toponymy of Azerbaijan (Āturpātakān)}

As an ancient country, Iran enjoys a wealthy toponymical heritage. During the centuries-old history, multiple ethnic groups and religions were created in the region, geographical changes took place, and wars and natural disasters annihilated one group of people and replaced them by others. Residential areas, mountains, and rivers were recurrently named and renamed by dwellers. However, an in-depth analysis of the present place names, together with the genealogical and etymological analysis of the available names allows to determine that, though tarnished by multilingual images, original Iranian toponyms are dominant in the territory. Turkic, Mongolian, or even Arabian penetration into Iran's toponymical system happened only through random historical events.

The Iranian nature of Āturpātakān is clearly visible in the toponymy of this land, which is distinguished for its wealth of Iranian elements even among the toponomastics of the predominantly Iranian-speaking provinces.

The author considered the toponymy of Āturpātakān from different aspects.

\section{Place Names Based on Their Origins}

1) Pre-Iranian Substrate Forms; 
2) Iranian Forms;

3) Mongolian \& Early Turkic Toponyms; and

4) Late Toponyms.

\subsection{Pre-Iranian Substrate Forms}

The toponym Xalxāl, for instance, a district name in south of Ardabīl, and Karkar, in East Azerbaijan which is a small village near Zunnūz, belong to the first group. Also, toponyms like Uskū (Oskū in modern pronunciation) a township to the south-east from Tabrīz (cf. Ašqaia-, Aškaia-, Uškaia- of the Urartian inscriptions) (Arutyunyan, 1985), as well as, possibly, Tabrīz, ${ }^{3}$ Qazvīn (cf. Kı $\sigma \beta i v a$ in Ptolemy, 6.2.17), Urmiya, Ušnuh, ${ }^{4}$ Hīrīs (<Hērīs), Sīs, Sīvān (or Sayvān), etc. belong in here.

\subsection{Iranian Forms}

The second group of the place-names in Azerbaijan includes very old names, first of all, the name of the province itself, Āturpātakān. The topoformant-ān is one of the most widespread suffixes in the Iranian toponymy, and might convey two meanings. First, it can be a plural marker $<$ Old Iranian*-ānām $>$, or it can be a patronymic suffix (<Middle Iranian-akān) (Assadorian 2007). The eponym Āturpāt (Greek Atropates, from Old Persian Aturpat “protected by fire”, c. 370 BC-after 321 BC) refers to a Persian trader and nobleman who served Dariush III, and founded a kingdom and dynasty that was named after him (Iranica, Vol. III, 2011). The ancient place names Sabalān (a mountain name), Zanjān, Xašīrān, Razgān, Dīmān, and many others, also belong to the same category.

Another ancient toponym in the region is Ardabil derived from ( $<^{*}$ Arta-waiti-, Arm. Artawēt), $<{ }^{\star}$ Arta-waiti- , arta- $<{ }^{*}$ ṛta-attested as "divine abundance, blessings" in Avesta (Aša-)., and the less frequently used, yet distinguished by its archaism, toponymic formant-bēl/-wīl (<wēl < OId Iranian * waiti-) meaning "full”, "ample". The same toponym is observed in the place names Andabill, with a-r- $>$ -n-phonetic change, (the names of two rural districts, one located 1.2 miles from Khalkhal in the Ardabil province, and another in Shabestar County, East Azerbaijan Province, $\check{S}_{u}$ räbīl (the name of a lake in the Ardabil province), as well as Lavandvill (near Astara, the capital of Astara County, Gilan Province).

\footnotetext{
${ }^{2}$ The toponyms with the element gargar-/karkar- (cf. the river Gargar in Kara-bakh) are attested also in the regions to the north from the Arax river, in Shirvan and Arran (in the historical Caucasian Albania and the eastern parts of Armenia), which points to the larger area of habitat of this pre-historical people (Eremyan, 1963), (Hübschman, 1969), (Hudūd al-'Alam "The Regions of the World", A Persian Geography edited by Minorsky (reprinted edition), 1982). On the whole, there are 16 names of localities (with Gargar), attested in the Armenian Highland and the surrounding areas Qarqa- in Qarqa-bāzār, the name of a small village near Tabrīz, can be hardly referred to in this connection, as it is, likely, a distorted form of the Armenian dialect kiraki-bazar, Sunday-market (Hakobyan et al., 1986).

${ }^{3}$ Markwart (1966: p. 275) considers it also possible that this toponym could have been further Iranized by analogy with the similar Iranian forms, implying a proto-form type of ${ }^{*}$ tapa-raiča-, cf. Nayriz , from * ni-raiča.

${ }^{4}$ Markwart (ibid: 269-270) believes that Ušnuh is an Iranian toponym, derived from OId Iranian.

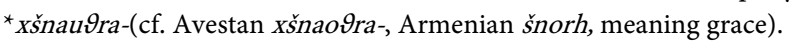




\subsection{Mongolian \& Early Turkic Toponyms}

The presence of Mongols and Turks in Iran has gradually and increasingly caused the replacement of Iranian names with those of Turkish and Mongolian toponyms. To this third group belongs $S a^{-} \bar{i} n$, a village, which lies in the south of Ardabīl (cf. also Sā'inn-gedük, a pass between Ardabīl and Saräb; gedük in Turkish means “a pass”), Ājārī, in Šāhīn-dēž, etc. (Minorsky, 1957).

\subsection{Late Toponyms}

Late toponyms consist of place names that are chosen to refer to the suburban, and/or industrial new towns, or replace those names that for whatever reason do not match the novel circumstances, be it political, social, etc. Some of the names in this category are simply made by single nouns or adjectives like (Pardis, Andišeh, Arjmand, Parand, etc.), and some others carry older Iranian topoformants like -ābād, ('Ali-ābād, Hiājūiābād), -šahr, (Eslāmšahr, Meškinšahr), -dašt, (Pākdašt, Māhdašt) and others. Finally, some obvious Persian/Turkic/Arabic formations (Pīr-zādeh, Qal'e, Qara-dāylū, Qešlāq-čày, etc.) are seen in this category.

\section{Place Names Based on Their Meanings}

\subsection{Toponyms Derived from Regional Characteristics}

Toponyms that have originated from the specific regional characteristics and landmarks form maximal number of place names in Iran. These names were mainly formed due to the frequency of occurrence of plants and animal species in a given area, geographic landmarks, and climatic conditions. Examples are Kajāb (tilted waterway), Golābād (where flowers are abundant), Šūrābad (place with salty water), etc.

\subsection{Hydronyms}

Many place names that initially have been hydronyms are classified in this category. Examples are Rūdbār (having plenty of rivers), Simminnrūd (silver river), $K o h a ̄ b$ (where water runs from the mountain).

\subsection{Toponyms Derived from Natural Phenomena, Residents' Occupations, Ethnonyms}

This category of names include those toponyms that bear names derived from natural phenomena, like Asbrāhān (path for horses); local residents' occupations and businesses, like Güšstpazān (those who cook meat), Ābforūšān (those who sell water); and ethnonyms like Xalxāl (discussed above), Gorjābād (where migrant Georgians live).

\subsection{Eponyms}

A number of place names refer to the name of the founder or conqueror of that town or village. Examples are Äturpātakān (as discussed above), Alidār, Hoseynābād (both names simply derived from Islamic religious figures and a 
place topoformant).

\subsection{Toponyms Based on the Religious Beliefs of the Residents}

The history of religion is extremely rich in Iran. This fabulous heritage is well reflected in the geographical names of the area revealing various religious practices from idolatry to Zoroastrianism, and from Buddhism to Christianity (Malandra, 1983), for the diversity of religions in ancient Persia. Vast investigations conducted by archaeologists and local explorers imply the existence of old cultures and worshipping markers like plantain, willow, pomegranate, and myrtle trees to which worshippers would hang pieces of their clothes, or sacred oil coated stones that were found near holy places. Frequently, these places were named after those trees, or the religious personalities buried in the vicinity.

\section{Place Names Based on the Word Formation of the Toponyms}

\subsection{Simple Toponyms}

There are a few Iranian toponyms made up of simple words. These are usually the names of geographical borders, ethnonyms, single word modifiers, or even the names of plants. Examples are Borj (tower) in Bojnourd, Khorasan province, Gargar (ethnonym) (in Kurdistan province), Xānik (land of rivers and springs) in Gonbad, Khorasan province, Alborz (a mountain name) the center of Alborz province, etc.

\subsection{Compound Toponyms}

A considerable number of Iranian toponyms are categorized as compound place names and are often made of two nouns, a noun and a suffix, a prefix and a noun, or a combination of two or all of the mentioned ones. Čăh Ali (Ali's well) in Sistan va Baluchestan province, Češme gol (flower spring) in Khorasan Razavi province, Kaläte Torkhā (a dwelling place of Turks) in Khorasan province, Deh pāy bìd (a village in the foot of a willow) in Kerman province, etc.

\subsection{Toponyms Containing Topoformants}

The majority of Iranian toponyms fall in this category. These are mainly place names that include particles which make toponyms. Examples are Äzerbāijan, Ardabīl, Zanjān, Tehrān, Dastgerd, and a lot more.

\subsection{Complex Toponyms}

Distinguishing the compound names from those of the complex ones is a complicated issue. However, in a number of toponyms, particularly those containing cardinal numbers, they are distinctively clear. Examples are Davāzdah emām (12 imams) in Charmahal va Bakhtiari province, Panj angošt (5 fingers) in Kerman province, Čehel češme (40 springs) in Fars province, sìyo se marde (33 men) (in Kurdistan province), etc. 


\section{6. Šām-Aspī: A Toponym from Ardabil}

As a place-name of the Iranian origin, i.e. pertaining to the fifth group of the above classification (5.3 Toponyms Containing Topoformants), we can refer to the toponym, $\check{S} \bar{a} m$-aspi, which is the name of a small village near Ardabill, to the left from the main road to Āstārā. ${ }^{5}$ Local people, identify the first part of this name with Šăm meaning "Syria" in Persian, and interpret it as a place where "Syrian brought horses dwell in". However, the toponym seems to be an old compound and, therefore, the folk interpretation of $\check{S} \bar{a} m$ can hardly be satisfying. The final $-\bar{i}$ points to a patronymic formation, considering which we can reconstruct the Middle Iranian form of this place name as ${ }^{\star} \check{S} \bar{a} m a s p \bar{k} k$, or ${ }^{*}$ Šămāspīk, i.e. "a village under the control of (or founded by) ${ }^{\star} \check{S} \bar{a} m a \bar{s} p$ ", the latter being a well-known personal name, from OId Iranian *S(i)yāmāspa-“(a man) having black or dark studs" (Mayrhofer, 1973), ${ }^{6}$ (cf. Avestan Syāvaspi-, Armenian $\breve{S}$ awasp) with the secondary dissimilation of the initial $s$ - to $\check{s}$ - (Assadorian, 2009).

\section{Research Methodology}

The survey is a consistent application of several methods. Linguistic, statistical, and geographical analyses, as well as historiographical methods were used simultaneously. Through the linguistic analysis, the Iranian word formation procedures and methods were investigated diachronically; around 52 topoformant (examples are -asp, -ābād, -bil, -gerd) suffixes were identified in a corpus of over 12,000 Iranian place names; topoformants' linguistic attributes and meanings were analyzed; and toponyms made from those suffixes as well as their frequency of occurrence was reported.

\section{Research Goal}

The goal of this study is to suggest a systematic classification for the Iranian toponymy; provide a synchronic and diachronic analysis of a great number of place names; identify topoformant suffixes and their origins, study their frequency and distribution, in order to help clarify some historical events, geographical changes, and political developments, and create an opportunity for the new language design to maintain the nature of the language in a way that matches the system, and stays attached to the old heritage.

The study is significant in that it presents a systematic classification of the Iranian toponymy having a comprehensive corpus of almost all place names available. The material and the results can contribute to the study and clarification of the present place names in Iran and the neighboring countries as well as the issues raised among them. Moreover, the topoformant suffixes collected in the survey can be of paramount significance in discovering the etymology of the

${ }^{5}$ Cf. Farhang-e jo jrafyāyī-ye ābādīhā-ye kešvar-e jomhūrī-ye eslāmī-ye İrān, Ardabīl, Vol. 8, Tehran, 1371/1992: 111.

${ }^{6}$ In Old Iranian we had two parallel variants of the lexeme meaning "black, dark": * $s(I) y a ̄ w a-$ and

${ }^{*} s(i)$ yäma-, with $-w$ - and $-m$-. 
place names, the origins of their early settlers, their distribution, and paths of immigration.

\section{Conclusion}

Iranian toponymical studies have been limited and scattered and the lack of a comprehensive and scientific research is profoundly felt. The systematic classification of toponyms and the topoformant affixes can methodologically serve as a fundamental base to conduct any scientifically reliable research on the toponymy of the region.

In an ancient country like Iran, toponymical studies are a necessity not only for understanding how the place names were created and formed, but also because they can solve many ethnological enigmas in the history of nations from India to Asia Minor and the Caucasus.

Regardless of the variety and complexity of the Iranian place names, due to the antiquity of the region, numerous historical events, vast ethnic migrations, and a great number of other phenomena, the accurate and scientific etymology of the toponyms allows us to identify the prevalent Iranian layers and proves that the random invasions of Mongol, Turk, and Arabian layers are only due to certain historical events of a given period.

Different categorizations were applied on the collected data based on the origin (pre-Iranian substrate forms, Iranian forms, Mongolian and early Turkic toponyms, and late toponyms), meaning (toponyms derived from specific characteristics of the region and peoples' businesses, hydronyms, ethnonyms, eponyms, and religious names), and the word formation (simple, compound, and complex) of the toponyms.

New toponymical suggestions can be made to unify the toponymical system and preserve and maintain the old heritage.

\section{References}

Arutyunyan, N. (1985). Toponimika Urartu (pp. 48). Erevan: Yerevan State University.

Assadorian, A. (2007). On the Toponomy of Ardabil (Vol. V, pp. 6-8). Orientalia, Yerevan: EEK Publications.

Assadorian, A. (2009). Šăm-aspī ( A Toponym from Ardabī), Iran and the Caucasus (Vol. 9, pp. 33-36). Leiden: Brill.

Eremyan, S. (1963). Armenia According to the Ashkharatsuyts. Yerevan: Academy of Sciences of Armenian SSR. (In Armenian)

Farhang-e jơrāfyāyīī-e Īrān (1949-1982). Ābādīhā-ye kešvar-e Jomhūrī-ye Eslāmī İrān (Vol. 1-138). Tehran: Entešār-e setād-e kol-ee arteš

Farhang-e jơrafyāyī-ye ābādīhā-ye kešvar-e jomhūrī-ye eslāmī-ye Īrān, Ardabīl (1992). Vol. 8, Tehran: P 111.

Hakobyan, T., et al. (1986). Hayastani ew harakic' šrjăanneri tetanunneri bararan (Vol. 1, A-D). Erevan: Yerevan State Publication.

Hübschman, H. (1969). Die altarmenischen Ortsnamen (pp. 273-274). Amsterdam: Oriental Press. 
Hudūd al-'Alam "The Regions of the World", A Persian Geography 372 A.H.-(982 A.D.), 396, fn. 2, also p. 214.

Iranica, E. (2011). Online Edition, New York, Vol. III.

Kasravī, A. (1918). Nāmhā-ye šahrhā va dehhā-ye İān, daftar-e yekom (pp. 270-289). Ārmān, Tehran: Entešārāt-e mouqūfāt-e Mahmūd Afšār Yazdī.

Kasravī, A. (1919). Nāmhā-ye šahrhā va dehhā-ye İrān, daftar-e dovvom (pp. 291-313). Ārmān, Tehran: Entešārāt-e mouqūfāt-e Mahmūd Afšār Yazdī.

Malandra, W. (1983). An Introduction to Ancient Iranian Religion: Readings from the Avesta and the Achaemenid Inscriptions. University of Minnesota Press. http://www.jstor.org/stable/10.5749/j.ctttsv8v

Markwart, J. (1966). "La province de Parskahayk", RÉArm., N.S., tom III, 269-270, 275.

Mayrhofer, M. (1973). Onomastica Persepolitana: Das Altiranische Namengut der Perseplis-Tafelchen (No. 293, pp. 75). Wien: Verlag der Osterreichischen Akademie der Wissenschaften.

Minorsky, V. (1957). Mongol Place-Names in Mukri Kurdistan (Mongolica 4), BSOAS (Vol. 19, pp. 58-81). London: University of London.

Submit or recommend next manuscript to SCIRP and we will provide best service for you:

Accepting pre-submission inquiries through Email, Facebook, LinkedIn, Twitter, etc. A wide selection of journals (inclusive of 9 subjects, more than 200 journals)

Providing 24-hour high-quality service

User-friendly online submission system

Fair and swift peer-review system

Efficient typesetting and proofreading procedure

Display of the result of downloads and visits, as well as the number of cited articles

Maximum dissemination of your research work

Submit your manuscript at: http://papersubmission.scirp.org/

Or contact aa@scirp.org 